\title{
Ecological Survey of Valuable Non-Timber Plant Resources in Two Rain forest Reserves in Southeastern, Nigeria *Olajide, O. and *Udofia S.I.
}

\begin{abstract}
The density and diversity of plant species producing valued non-timber products in two moist rainforests in Southeastern Nigeria were studied. The two forests are Cross-River North Forest Reserve, Cross River State and Stubbs Creek Forest Reserve, Akwa Ibom State. Twenty- three plant species with the distribution as Trees (7), Palms (1), Shrubs (6), Climber (5), and Herbs (4), were assessed in the Cross River North Forest Reserve, while twelve species with the distribution as trees (2), Palms (2), Shrubs (2), Climbers (3), and herbs (3) were assessed in the Stubbs Creek Forest Reserve. Shannon-Wiener's diversity indices result (D) in the Cross River North Forest Reserve, showed $D$ of 2.12, 0.30, 1.50, 1.20 and 1.51 respectively for trees, palms, shrubs, herbs and climber while in the Stubbs Creek Forest Reserve D result of 0.60,0.60,0.60, 0.90 and 0.91 respectively were recorded for trees, palms, shrubs, herbs and climbers.
\end{abstract}

KEYWORDS: $\quad$ Rainforests, Non-Timber Products, Diversity-Indices, Sustainable Management

\section{Introduction}

he tropical rainforest is the most
biological diverse terrestrial ecosystem on earth (Whitmore, 1998, Turner 2001 and the Gillespie et al 2004). It is the predominant natural forest in Nigeria. The rainforest occupies about $10 \%$ of Nigeria landmass (Akinsanmi and Akindele, 2002). The Nigeria rainforest have extensively been degraded and mostly now in patches.

The forests have been sources of livelihood of many people from time immemorial. The rainforests have been managed exclusively over the years for timber production. In other words, the density of timber trees is often the only yardstick for determining the value of a tract of rainforest. The forest is erroneously viewed as a crop merchantable trees rather than an interdependent, high diversity ecosystem of potential multiple value (Panayotou and Ashton, 1992; Olajide, 2003). The erroneous view has culminated in gross under- valuation of the rainforest as various non-timber plant resources which in most cases are much more valuable than timber resources are ignored.

Accordingly, a considerable area of rainforest, poor in timber tree species, but often heavily stocked with diversity of valuable non- timber resources has been replaced with monoculture forests of mostly fast-growing exotic species like Gmelina (Gmelina arborea), Teak (Tectona grandis) and Eucalypts (Eucalyptus spp.). The monoculture stands of these trees often impair the existence of many valuable native plant species particularly the undergrowth species
(Mgeni, 1991). Among the valuable nontimber resources of rainforests are edible and medicinal fruits, seeds, leafy vegetables, twigs, nuts and bark; rattan, gum, latex, tanni and dyes.

In contrast to timber exploitation, exploitation of non- timber products causes infinitesimal or negligible perturbation in the ecosystem. Ford foundation (1998) averred that the non- timber forest products (NTFPs) are particularly important part of multiple- use strategies, because they increase the range of income generating options of forest-dependent villagers while avoiding some of the ecological costs of timber cutting. This paper, therefore, is a report of the study on diversity and densities of commercially valued nontimber plant resources in two moist rainforests in southeastern Nigeria. It is hoped that the findings would foster sustainable multiple use management of the forests.

Study Area

The study was carried out in the Cross River North Forest Reserve, Cross-River State and Stubbs Creek Forest Reserve, Akwa Ibom State, Southeastern Nigeria

Cross River North Forest Reserve lies between latitudes $6^{\circ} 08^{\mathrm{I}}$ and $6^{\circ} 26^{\mathrm{I}} \mathrm{N}$ and longitudes $8^{\mathrm{O}} 50^{\mathrm{I}}$ and $9^{\circ} 05^{\mathrm{I}} \mathrm{E}$. The Forest Reserve covers a total area of 12,950 hectares. The area has an annual rainfall of about $2500 \mathrm{~mm}$. The mean minimum and maximum annual temperatures are $24^{\circ} \mathrm{C}$ and $30^{\circ} \mathrm{C}$ respectively. The mean annual relative humidity is about $78 \%$ while the soil is ferric lvisol underlain by basement complex.

*Department of Forestry and Wildlife University of Uyo, Akwa Ibom State. Nigeria yemisola 2000@yahoo.com 
The Stubbs Creek Forest Reserve lies approximately between latitudes $4^{\circ} 32^{1} \mathrm{~N}$ and $4^{0} 38^{1} \mathrm{~N}$ and between longitudes $8^{\circ} \mathrm{E}$ and $8^{\circ} 20^{1}$ E. It covers an area of about 15,000 hectares. The mean annual rainfall of the area is between $2400 \mathrm{~mm}$ and $3000 \mathrm{~mm}$. The mean minimum and maximum temperature are $26^{\circ} \mathrm{C}$ and $30.5^{\circ} \mathrm{C}$ respectively while the mean relative humidity of the area is about $83 \%$. The forest is growing on silt loam soil.

Materials and Methods

Three $1 \mathrm{~km}$ transects were laid randomly at 20 metres away from and perpendicular to the access route into each of the two Forest Reserves. The plant species within 20 metres away from both sides of each transect which produce valuable non- timber products were enumerated. It therefore summed up to an area of $120,000 \mathrm{~m}^{2}$ (12ha) assessed in each of the two Forest Reserves. The enumerated plant species were classified into five life-forms of Trees, Palms, Shrubs, Climbers and Herbs. The data were collected during dry and rainy seasons between years 2003 and 2005.

The mean population density per hectare of each species was determined from its population in the 12 ha area assessed. Species diversity indices (D) were determined with Shannon -Wiener information function (Bhandari, 2003). The function is of the form:

$$
\left.\mathrm{D}=\sum_{\mathrm{i}=1}^{\mathrm{S}}\left(\frac{\mathrm{n}_{1}}{\mathrm{~N}}\right) \underset{\log _{2}}{\frac{\mathrm{N}}{\mathrm{n}_{1}}}\right)
$$

Where,

$\mathrm{D}=$ Shannon - Wiener index of species diversity

$\mathrm{n}_{\mathrm{i}}=$ density of the species $\mathrm{i}$

$\mathrm{N}=$ total density of all the species

$\mathrm{S}=$ total number of species involved.

\section{Results}

Twenty three (23) plant species were identified and enumerated in the Cross River North Forest Reserve. The tree life-form had the highest representations of 7 species. This was followed by shrub (6), climbers (5) herb (4) and palm (1). The population of individual plant species varied (Table 1). In the tree category, Pentacletra macrophylla had the highest population of 222 per hectare, while Petersia africanum, tetrapleura tetraptera and
Dacryodes edulis had the least of 3 frequencies apiece per hectare. Lasienthra africana had the highest population of 164 per hectare in the shrub category, while Lecanodiscus cupaloides had the least of 3 per hectare.

Palm was represented by only Elacis guineensis with a population of 39 per hectare. In the climber life form, Ancistrophyllum secundiflorum had the highest population of 122 per/ha, while Dioscorea bubifera had the least of 7 per/ha. Thaumatococcus danielli had the higest population of $3025 \mathrm{per} / \mathrm{ha}$ in the herb category while Gongronema latifolum had the least of $67 \mathrm{per} / \mathrm{ha}$. The population of each of the species enumerated in the Cross River North Forest Reserve and the nontimber products derived from them are contained in Table 1.

In the Stubbs Creek Forest Reserve, 12 plant species were enumerated. Tree was represented by 2 species, shrub (2 species), climber ( 3 species) and herb (3 species). In tree category, Mitragyna ciliata had the highest population of $11 \mathrm{per} / \mathrm{ha}$, while Tetrapleura tetraptera had the least of 7 per/ha. Under palm, Raphia spp. had the highest population density of $333 \mathrm{per} / \mathrm{ha}$, while Elaeis guineensis had 8 per/ha. Lasienthera africana had the highest population density of $375 \mathrm{per} / \mathrm{ha}$ in shrub category while Randia spp had the least of $28 \mathrm{per} / \mathrm{ha}$. Under herb, Thaumatoccocus danielli had the highest population of 308 per/ha followed by Piper guineensis (3 per/ha). Calamus deeratus was assessed to have the highest population density of $2325 \mathrm{per} / \mathrm{ha}$ in the climber category, and followed by Ancistrophyllum secundiflorum with the population of 2028 per/ha and Gnetum africana had the least of $33 \mathrm{per} / \mathrm{ha}$. The population density of each of the plant species encountered in Stubbs Creek Forest Reserve and their non-timber products are contained in Table 2. Diversity indices (D) of $2.12,0.30,1.50,1.20$ and 1.51 were calculated respectively for trees, palms, shrubs, herbs and climber in the Cross River North Forest Reserve. In the case of the Stubbs Creek Forest Reserve, 0.60, 0.60, 0.60, 0.90 and 0.91 are the diversity indices calculated respectively for tress, palms shrubs, herb and climbers. 


\section{Discussion}

The tropical rainforest resources are not homogenous but differ in species composition and structure (Turner, 2001 Gillespie et al 2004). There are also differences within, between and among tropical rainforest resources in different locations.

However, the existence of a plant species in a forest ecosystem is a function of the prevailing microclimates in the forest. Different microsites with varying microclimates are often created in forest consequence of natural and artificial perturbations. Different microsites provide niches for different plant species or group of pant species. The variation in the population densities of the plant species enumerated can probably be influenced by different sizes of niches in the forests. Distribution of tree regeneration and tree species' coexistence have been found to be influenced by different microsites in temperate and tropical rainforests (Dalling and Hlubbell, 20-02; Christie and Armesto 2003). The existence or nonexistence of a plant species is dependent on a number of factors. The effects of the factors vary from one species to another. However, a sufficient availability of viable seeds, appropriate climate and edaphic conditions for seed germination and establishment of the plant are indispensable for the existence of any plant species (Richards, 1996). Also, the population of individual plant species may be influenced by the varying exploitation intensities.

The generally higher diversity indices calculated for all the groups of plants in Cross

\section{References}

Akinsanmi, F.A and S.O Akindele (2002). Timber Yield Assessment in the Natural Forest Area of Oluwa Forest Reserve, Nigeria. Nigerian Journal of Forestry Vol.32

(1):16-22.

Bhandari, B.S. (2003). Blue Pine (Pinus watichiana) forest stands of Garhwai Himalaya: Composition, Population Structure and Diversity. Journal of Tropical Forest Science 15 (1): 26-36.

Christie, D.A and J.J. Armesto (2003). Regeneration of Microsite and tree species coexistence in temperate rainforest of Chilue Island, Chile. Journal of Ecology 91 (15): 776-784.

Dalling, J. W. and S.P. Hubbell (2002). Seed Size, Growth Rate and gap microsite conditions as
River North Forest Reserve when compared with Stubbs Creek Forest Reserve may be due to the greater degree of degradation to which the latter had suffered.

Devi and Behera (2003) calculated higher diversity indices for the trees, shrubs, lianas and herbs in a relatively undisturbed natural forest as against lower indices in a disturbed natural forest in India. Nath et al (2005) reported higher population of undergrowth species as compared with tree species in a disturbed tropical rainforest in Northeast India. A species with less than ten individuals per hectare is considered as a rare and endangered species (Parthasarathy and Karthikeyan, 1997). Accordingly, Dacryodes edulis, Diospyrous Spp; Parkia bicolor, Petersia africanum, Tetrapleura tetraptera, Heinsia crinata, Lacaconodiscus cupaloides, Rinorea gracilipes and Dioscorea bubifera can be deemed rare species in the Cross River North Forest Reserve, while same can be said of Tetrapleura tetraptera, Elaeis guineesis, Gongronema latifolium and Piper guineensis in the Stubbs Creek Forest Reserve.

\section{Conclusion}

This study has revealed the abundance of ecologically valuable non-timber forest plants in the study area. Sustainable management of forest reserves requires holistic approach in which both timber and non-timber forest plants are managed in accordance with their ecological attributes. The present only timber management objective need to be reviewed to incorporate multiple value management strategies.

determinants of success for pioneer species. Journal of Ecology 90: 557-568.

Devi, U and N. Behera (2003). Assessment of Plant Diversity in Response to Forest Olegradation in a Tropical Dry Deciduous Forest of Eastern Ghats in Orissa. Journal of Tropical Forest Science 15 (1) 147-163.

Ford Foundation (1998). Forestry for Sustainable Rural Development: A review of Ford Foundation Community Forestry Program in Asia. 58p.

Gillespie, T. W., Brock, J. and C.W Wright 2004. Prospects of Quantifying Structure, Floristic Composition and species Richness of Tropical Forests. International Journal of Remote Sensing 25 (14) :70-77. 
Mgeni, A. S. M. (1991). A More Efficient state: Natural Forest or Plantation. In Pyatt, N. and T. Williams (eds.). Tropical Forestry: Third World Priorities Versus Western Concerns, pp 43-58.

Nath, P. C. Arunachalam, A. Khan, M. L Arunachalam, K and A. Barhuiya (2005). Vegetation analysis and tree population structure of Tropical wet evergreen Forests in and Around Namdapha National Park, Northeast India. Biodiversity and Conservation. 14: 2109-2136.

Olajide, O. (2003). Steps Towards Sustainable Natural forest Management for Non-timber Forest Products in Nigeria. In: Akindele, S. O. and L. Popoola (eds.) Community Forestry and Stakeholders' Participation in Sustainable Development. pp 303-308.

Panaytou, T. and P.S. Ashton (1992). Not by timber

Alone: Economics and Ecology for Sustaining
Tropical Forests. Island Press, Washington D.C. and Covelo, California, U.S.A.

Parthasarethy, N. and R. Karthikeyan (1997) Biodiversity and Population Density of Woody species in a Tropical Evergreen Forest in Courtallum Reserve Forest, Western Ghats, India. Tropical Ecology 38:297-306.

Richards, P.W (1996). The Tropical Rainforest: An Ecological Study $2^{\text {nd }}$ Edition, Cambridge, University Press, Cambridge, 450p.

Turner, I.M. (2001). The Ecology of Trees in the Tropical Rainforest Cambridge University Press, Cambridge, U. K. 298p.

Whitmore, T.C (1998).An Introduction to Tropical Rainforsts. Oxford University Press Inc. New York 282p.

Table 1: Valuable Non-Timber Plant Species and Products in the Cross River North Forest Reserve, Southeastern Nigeria

\begin{tabular}{|c|c|c|}
\hline Scientific Name & Population Density (Per/ha) & Non-Timber Products \\
\hline \multicolumn{3}{|l|}{ TREE } \\
\hline Brachystegia eurycoma & 28 & $\begin{array}{l}\text { Grounded seed used as soup } \\
\text { thickening }\end{array}$ \\
\hline Dacryodes edulis & 3 & Edible fruit \\
\hline Diospyrous spp & 8 & Medicinal bark \\
\hline Parkia bicolor & 6 & Edible seeds \\
\hline Pentaclethra macrophylla & 222 & Edible seeds \\
\hline Petersia africanum & 3 & Medicinal leaves \\
\hline Tetrapleura tetraptera & 3 & Spicy and medicinal fruit \\
\hline \multicolumn{3}{|l|}{ PALM } \\
\hline Elaeis guineensis & 39 & $\begin{array}{l}\text { Edible oil from seed's mesocarp and } \\
\text { nuts: wine from sap, broom from } \\
\text { midrib of leaflets }\end{array}$ \\
\hline \multicolumn{3}{|l|}{ SHRUB } \\
\hline Carpolobia hitea & 36 & $\begin{array}{l}\text { Sticks for shepherding cattle; } \\
\text { chewing stick and medicinal bark. }\end{array}$ \\
\hline Heinsia crinata & 6 & Edible leafy vegetable. \\
\hline Lasienthera africana & 164 & $\begin{array}{l}\text { Medicinal and edible leafy } \\
\text { vegetable }\end{array}$ \\
\hline Lecanodiscus cupaloides & 3 & Edible fruit \\
\hline Randia spp & 25 & Chewing sticks \\
\hline Rinorea gracilipes & 7 & Chewing sticks \\
\hline \multicolumn{3}{|l|}{ HERB } \\
\hline Afromomum sceptrum & 253 & $\begin{array}{l}\text { Edible fruit and pulp; medicinal } \\
\text { rhizome }\end{array}$ \\
\hline Gongronema latifolium & 57 & $\begin{array}{l}\text { Leafy vegetable; edible and } \\
\text { medicinal raw leaves. }\end{array}$ \\
\hline Piper guineensis & 67 & $\begin{array}{l}\text { Edible and medicinal leafy } \\
\text { vegetable and seeds; }\end{array}$ \\
\hline Thaumatococus danielli & 3025 & Leaves for rapping food \\
\hline \multicolumn{3}{|l|}{ CLIMBER } \\
\hline Ancistrophyllem secundiflorum & 128 & $\begin{array}{l}\text { Cane for furniture making, leaves as } \\
\text { roofing materials }\end{array}$ \\
\hline Calamus deeratus & 61 & $\begin{array}{l}\text { Cane for furniture making leaves as } \\
\text { roofing materials }\end{array}$ \\
\hline Combretum albidum & 25 & Sponge from the pulp \\
\hline Dioscorea bubifera & 6 & Medicinal tuber \\
\hline Gnetum africanum & 33 & Leafy vegetable \\
\hline
\end{tabular}


Table 2: $\quad$ Valuable Non-Timber Plant Species and Products in the Stubbs Creek Forest Reserve, Southeastern Nigerian.

\begin{tabular}{|c|c|c|}
\hline Scientific Name & Population Density (Per/ha) & Non-Timber Product \\
\hline \multicolumn{3}{|l|}{ TREE } \\
\hline Mitragyna ciliata & 11 & Leaves are used for kolanut preservation \\
\hline Tetrapleura tetraptera & 7 & Spicy and medicinal fruit. \\
\hline \multicolumn{3}{|l|}{ PALM } \\
\hline Elaeis guineensis & 8 & $\begin{array}{l}\text { Edible oil from seed's medsocarp and } \\
\text { nuts, wine from sap; broom from midrib } \\
\text { of leaflets }\end{array}$ \\
\hline Raphia spp & 333 & $\begin{array}{l}\text { Wine from sap; leaf's midrib for furniture } \\
\text { making. Leaflets for roofing and midribs } \\
\text { of leaflets as broom }\end{array}$ \\
\hline \multicolumn{3}{|l|}{ SHRUB } \\
\hline Lasienthera africana & 375 & Medicinal and edible vegetable \\
\hline Randia spp & 28 & Chewing stick \\
\hline \multicolumn{3}{|l|}{ HERB } \\
\hline Gongronema latifolium & 3 & $\begin{array}{l}\text { Leafy vegetable ; edible and medicinal } \\
\text { raw leaves }\end{array}$ \\
\hline Piper guineensis & 6 & $\begin{array}{l}\text { Edible leaf vegetable and seeds, leaves } \\
\text { and seed are medicinal }\end{array}$ \\
\hline Thaumatoccocus danielli & 308 & Leaves for rapping food \\
\hline \multicolumn{3}{|l|}{ CLIMBER } \\
\hline Ancistrophyllum secundiflorum & 2028 & $\begin{array}{l}\text { Cane for furniture making and leaves } \\
\text { roofing materials }\end{array}$ \\
\hline Calamus deeratus & 2325 & $\begin{array}{l}\text { Cane for furniture making; leaves as } \\
\text { roofing materials }\end{array}$ \\
\hline Gnetum africanum & 33 & Leafy vegetable \\
\hline
\end{tabular}

